\title{
Antitumour activity of miltefosine alone and after combination with platinum complexes on MXT mouse mammary carcinoma models
}

\author{
Thilo Spruß ${ }^{1}$, Günther Bernhardt ${ }^{1}$, Helmut Schönenberger ${ }^{1}$, and Jürgen Engel ${ }^{2}$ \\ 1 Universität Regensburg, Institut für Pharmazie, Universitätsstr. 31, W-8400 Regensburg, Federal Republic of Germany \\ 2 Asta Medica, W-6000 Frankfurt/M., Federal Republic of Germany
}

Received 24 September 1991/Accepted 29 June 1992

\begin{abstract}
Summary. Miltefosine, an alkylphosphocholine structurally related to alkyllysophospholipids showed highly selective antitumour activity against the hormone-sensitive variant of the s.c. transplantable MXT mouse mammary adenocarcinoma, the ovary-dependent MXT (M3.2), whereas it was inactive against the hormone-insensitive MXT (M3.2) OVEX variant. A dose of $32 \mathrm{mg} / \mathrm{kg}$ miltefosine p.o. daily for 5 weeks was well tolerated. Histopathological evaluation gave no signs of gastroenteral toxicity. After therapy the microarchitecture of the MXT (M3.2) tumours changed from that of a moderately differentiated adenocarcinoma to that of an anaplastic mammary carcinoma. A dose of $16 \mathrm{mg} / \mathrm{kg}$ miltefosine p.o. daily, though in effective per se, enhanced the antitumour activity of suboptimal i.p. doses of cisplatin and the hormone-like platinum analogue [meso-1,2-bis(2,6-dichloro-4-hydroxyphenyl)ethylenediamine]dichloroplatinum(II). Furthermore, it was shown, that miltefosine exhibited no (anti)hormonal properties. However, the mechanism of action of miltefosine remains unclear.
\end{abstract}

Key words: Miltefosine - Cisplatin analogues - MXT mouse mammary tumours - Combination therapy

\section{Introduction}

Miltefosine, a new alkylphosphocholine, shows high in vivo antitumour activity against the autochthonous experimental hormone-sensitive dimethylbenz $[a]$ anthracene- and the methylnitrosourea-induced rat mammary tumour models (Muschiol et al. 1988; Hilgard et al. 1990a,b) rather than against transplantable tumours (Scherf et al. 1987; Hilgard et al. 1988; Yanapirut et al. 1991) with the exception of the hu-

Abbreviation. Complex A, [meso-1,2-bis(2,6-dichloro-4-hydroxyphenyl)ethylenediamine]dichloroplatinum(II)

Correspondence to: T. Spruß man KB squamous epithelial carcinoma xenografts in nude mice (Hilgard et al. 1991).

In phase I clinical studies the topical application of miltefosine led to the reduction of skin metastases of patients suffering from breast cancer (Unger et al. 1990a,b; ten Bokkel Huinink et al. 1992).

Various hypotheses on the mechanism of action of miltefosine, such as interference with phospholipid metabolism (Haase et al. 1991), inhibition of protein kinase C (Shoji et al. 1991; Überall et al. 1991) or Na/K-ATPase (Zheng et al. 1990) have been proposed.

In contrast to the structurally related alkyllysophospholipids (Andreesen and Munder 1990) miltefosine lacks immunomodulatory activity (Hilgard et al. 1991), whereas modulation of differentiation processes seems to be involved in tumour regression caused by alkyllysophospholipids (Honma et al. 1981; Honma et al. 1983) and miltefosine, respectively (Hochhuth et al. 1990; Hilgard et al. 1989). However, there is controversy if miltefosine is an inducer (Hochhuth et al. 1990) or inhibitor (Shoji et al. 1991) of tumour cell differentiation.

Very recently in vitro synergism of ilmofosine, a $1-S$-thioetheralkyllysophospholipid derivative, and various antineoplastic drugs has been reported (Weisbrod et al. 1990; Herrmann et al. 1992a). De Cesare et al. (1992) found that the in vivo antitumour activity of cisplatin against human lung tumour xenografts was also significantly enhanced by ilmofosine. On a murine fibrosarcoma model a similar in vivo synergism of ilmofosine and cisplatin was observed by Herrmann et al. (1992b).

In order to investigate the contribution of differentiation and possible synergism of miltefosine and platinum complexes we chose the subcutaneously transplantable MXT mouse mammary carcinoma model existing in two variants (Watson et al. 1977, 1980). The hormone-independent MXT (M3.2) OVEX tumour is anaplastic whereas the ovary-dependent MXT (M3.2) variant is a moderately to well-differentiated adenocarcinoma. Histopathological evaluation including morphometric analysis of hormone-dependent MXT tumours should give further insight into the mode of action of miltefosine. 


\section{Materials and methods}

\section{In vitro studies}

Cell lines and culture conditions. The $\mathrm{MXT}^{+}$and $\mathrm{MXT}^{-}$cell lines were established after mechanical and enzymatic disintegration of vital tumour "tissue" of the ovary-dependent MXT (M3.2) and the hormone-insensitive variant MXT (M3.2) OVEX grown in untreated B6D2F, mice (Beckenlehner 1991). The cells were maintained in RPMI-1640 medium (Sigma, München) containing additional $0.6 \mathrm{~g} / \mathrm{l}$ L-glutamine (i.e. $0.9 \mathrm{~g} / \mathrm{l}), 2.0 \mathrm{~g} / \mathrm{/} \mathrm{NaHCO} \mathrm{H}_{3}, 10 \%$ fetal calf serum (Gibco, Eggenstein) and $50 \mathrm{mg} / \mathrm{l}$ gentamycin (Sebio, Walchsing). The hormone-sensitive $\mathrm{MXT}^{+}$ variant required $100 \mathrm{ng} / \mathrm{l}$ oestradiol (Sigma, München) supplementation, whereas $\mathrm{MXT}^{-}$cells were maintained without oestradiol. The cells were serially passaged following trypsinization using trypsin $(0.05 \%) /$ EDTA $(0.02 \%)$ (Boehringer, Mannheim) and cultured in a water-saturated atmosphere of $95 \%$ air and $5 \%$ carbon dioxide at $37^{\circ} \mathrm{C}$ in $75-\mathrm{cm}^{2}$ culture flasks (Costar, Tecnomara, Fernwald).

Chemosensitivity testing. For determining the antitumour activity of miltefosine in vitro a standardized kinetic microassay based on crystal violet staining was used. The technical details of the procedure and the method of evaluation of drug action have been discussed recently (Bernhardt et al. 1992). In brief: cells were seeded $(100 \mu \mathrm{l} /$ well $)$ in 96-well flat-bottomned microtitration plates (Costar, Tecnomara, Fernwald) at an appropriate density of approximately 15 cells/microscopic field (magnification 320x). After $42-48 \mathrm{~h}$ the culture medium was removed by suction and replaced by fresh medium ( $200 \mu \mathrm{l} /$ well) containing miltefosine or vehicle (double-distilled water). Miltefosine was added as a 1000 -fold concentrated stock solution. On every plate 16 wells served as controls and 16 wells were used for each drug concentration. After various times of incubation the cells were fixed with glutaraldehyde (Merck, Darmstadt) and stored in a refrigerator. At the end of the experiment all plates were stained with crystal violet (Serva, Heidelberg) simultaneously. Absorbance was measured at $578 \mathrm{~nm}$ using a Biotek 309 Autoreader (Tecnomara, Fernwald). Processing procedure, data analysis and evaluation were performed as described (Reile et al. 1990; Bernhardt et al. 1992). Results are presented as plots of absorbance or corrected treated/control $(T / C)$ values versus time of incubation according to: $T / C_{\text {corr }}(\%)=\left(T-C_{0}\right) /\left(C-C_{0}\right) \times 100$, where $T$ is the absorbance of the treated cells, $C$ is the absorbance of the controls, and $C_{0}$ is the absorbance of the cells at the time when drug was added $(t=0)$.

\section{In vivo studies}

Drugs. Miltefosine (see Fig.1) and cisplatin were gifts from Asta Medica (Frankfurt/M.). Tamoxifen citrate was purchased from Sigma (München). The [meso-1,2-bis(2,6-dichloro-4-hydroxyphenyl)ethylenedia-

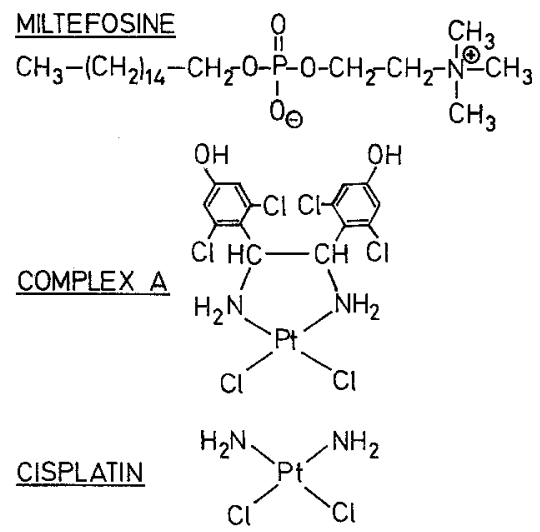

Fig. 1. Structure of miltefosine, [meso-1,2-bis(2,6-dichloro-4-hydroxyphenyl)ethylenediamine]dichloroplatinum(II) (complex A), and cisplatin
mine]dichloroplatinum(II) complex (see Fig.1, complex A) was synthesized and characterized as described by Karl et al. (1988).

Drug preparations. The vehicle for the platinum complexes and tamoxifen citrate was polyethyleneglycol 400 (PEG)/1.8\% $\mathrm{NaCl}(1: 1)$. These drugs were administered s.c. in an injection volume of $0.1 \mathrm{ml} / 20 \mathrm{~g}$ body weight as solution or suspension. Miltefosine was dissolved in doubledistilled water and administered p.o. in a volume of $0.2 \mathrm{ml} / 20 \mathrm{~g}$ body weight.

Animals and housing conditions. For all experiments with the MXT murine mammary carcinomas, 8-week-old female B6D2F, mice (Charles River Wiga, Sulzfeld) were used. Uterine weight tests were carried out with 21-day-old female NMRI mice (Charles River Wiga, Sulzfeld). Animals were housed in Macrolon cages (size III; Ehret, Emmendingen) at an ambient temperature of $21^{\circ} \mathrm{C}$ and with a $12 \mathrm{~h}$ light/dark cycle. The animals were fed with laboratory animal chow (H 1003; Alma, Kempten) and water was provided ad libitum.

\section{Tumours, transplantation procedure, treatment schedule, and evaluation of drug effects}

Ovary-dependent MXT (M3.2) and hormone-insensitive MXT (M3.2) OVEX tumours. A detailed description of the MXT variants used in this study and their growth characteristics have been published recently (Spruß et al.1991).

Experimental protocol. On day 0 (after s.c. implantation of about $2-\mathrm{mm}^{3}$ tumour pieces into the region of the right thoracal mammary fat pad) the animals were randomly assigned to groups of ten. Treatment was started on day 1 by injecting the platinum complexes, tamoxifen, and vehicle (PEG/saline) s.c. into the left flank, three times a week. Therapy with miltefosine and vehicle (double-distilled water) started on day 1 with the administration of the solutions p.o. with a gastro-oesophageal tube. Hormone dependence of the MXT (M3.2) tumour was checked by ovariectomy (on day 1) and tamoxifen treatment (Spruß et al. 1991).

Evaluation of drug effects. Parameters for evaluating antitumour activity were mean tumour area $\left(\mathrm{mm}^{2}\right)$ in the course of MXT (M3.2) and MXT (M3.2) OVEX experiments, and mean tumour wet mass at the end of the MXT (M3.2) experiments. Tumour area was calculated as the product of two perpendicular diameters, one measured across the greatest width.

Determination of relative uterotrophic activity. Relative uterotrophic activity of miltefosine was determined by p.o. administration of different doses of the compound to 21-day-old female NMRI mice (Charles River Wiga, Sulzfeld). Three days after treatment (on day 4) the uteri were fixed in Bouin's solution for $24 \mathrm{~h}$. Thereafter the uteri were cleaned from adhering fat and connective tissue, and dried at $100^{\circ} \mathrm{C}$. Uterotrophic activity is defined as uterine dry mass ( $\mathrm{mg}$ ) divided by body mass $(\mathrm{g})$. The mean uterotrophic activity of the test group divided by the mean uterotrophic activity of the corresponding control group, multiplied by 100 , gives the relative uterotrophic activity of a compound.

Histology and morphometric analysis of the tumours. For histological documentation and morphometric analysis the tumours were fixed in Bouin's solution. Paraffin sections $(5 \mu \mathrm{m})$ were stained according to the method of Masson and Goldner modified by Jerusalem. The nuclear areas of tumour cells were measured using an Olympus BH-2 microscope with a $60 \times$ SPlanApo (oil) objective (Olympus Optical Co. Ltd., Tokyo, Japan). The microscopic image was focused through a NFK $2.5 \times$ photoeyepiece to a Panasonic F10 CCD videocamera (Matsushita Communication Industrial Co., Osaka, Japan). For image analysis the video signal was transformed in a PIP-512/1024A video digitizer board (Matrox Electronic Systems Ltd., Quebec, Canada) installed in an Olivetti M24 personal computer (Ivrea, Italy) and visualized on a Sony PVM-1371 QM video monitor (Tokyo, Japan). The nuclei were encircled with a mouse and the nuclear areas were automatically calculated using an image-processing program written in TURBO PASCAL. Three tumours per treatment group were morphometrically analysed. Solid, non-necro- 
tic tumour regions from the abdominal side of the s.c. growing tumour were evaluated by measuring both 100 nuclei from highly differentiated structures and 100 nuclei from undifferentiated carcinoma cells.

Estimation of gastrointestinal toxicity. At the end of the MXT experiments animals were dissected. The tumour and the pars descendens of the duodenum of three animals per treatment group were fixed in Bouin's solution for histological evaluation.

Statistics. The $P$ values were calculated according to the Mann-Whitney $U$-test (Sokal and Rohlf 1987).

\section{Results}

\section{Chemosensitivity of $M X T^{2}$ and $M X T^{+}$cells against} miltefosine in vitro

The effect of three concentrations of miltefosine (1, 10 and $100 \mu M$ ) on the hormone-independent $\mathrm{MXT}^{-}$and the hormone-sensitive $\mathrm{MXT}^{+}$breast cancer cell line is demonstrated in Fig. 2. On the $\mathrm{MXT}^{-}$variant all three concentrations of miltefosine were ineffective (cf. Fig. 2A), whereas tumour cell proliferation of the $\mathrm{MXT}^{+}$cell line was strongly inhibited at the $100 \mu M$ dose (Fig. 2B).

\section{Effect of miltefosine on the MXT(M3.2) OVEX tumour in vivo}

Doses of $16 \mathrm{mg} / \mathrm{kg}$ and $32 \mathrm{mg} / \mathrm{kg}$ miltefosine (daily, p.o.) did not inhibit the proliferation of the hormone-independent MTX (M3.2) OVEX tumour.

\section{Effect of miltefosine on the MXT (M3.2) tumour in vivo}

The hormone dependence of the MXT (M3.2) mammary carcinoma was demonstrated by strong inhibition of tumour growth by the anti-oestrogen tamoxifen $(8 \mathrm{mg} / \mathrm{kg}$, three times weekly, s.c.) and by ovariectomy on day 1 after tumour transplantation (Fig. 3A). Growth of this tumour was also decreased by miltefosine treatment at a dose of $32 \mathrm{mg} / \mathrm{kg}$ (daily, p.o.), whereas a dose of $16 \mathrm{mg} / \mathrm{kg}$ was ineffective (Fig. 3B).

\section{Gastrointestinal toxicity of miltefosine}

Presumably miltefosine was non-toxic to the gastrointestinal tract, since the dissection of the mice showed no macroscopic changes. Histological examination revealed no alterations of mucosal cells of the pylorus and of the duodenum descendens that might have been caused by perorally administered miltefosine.

\section{Oestrogenic and anti-oestrogenic activity of miltefosine}

Since miltefosine was only active on the hormone-sensitive MXT variant (both in vitro and in vivo) we evaluated possible hormonal (i.e. uterotrophic or antiuterotrophic) activities of this alkylphosphocholine using the uterine weight test. Doses of $4 \mathrm{mg} / \mathrm{kg}, 8 \mathrm{mg} / \mathrm{kg}, 16 \mathrm{mg} / \mathrm{kg}$, and $32 \mathrm{mg} / \mathrm{kg}$ miltefosine were administered to 21-day-old NMRI mice perorally. The uterine weight test gave no indication for hormonal activity of miltefosine on the uterus of immature mice. Uterine weight tests at the end of MXT (M3.2) experiments also gave no indication of (anti)hormonal activity of miltefosine on the uterus of adult mice.

Combination therapy of the MXT (M3.2) tumour with miltefosine and platinum complexes

Cisplatin and the hormone-like platinum complex A were administered at suboptimal doses $(3 \mu \mathrm{mol} / \mathrm{kg}$, three times
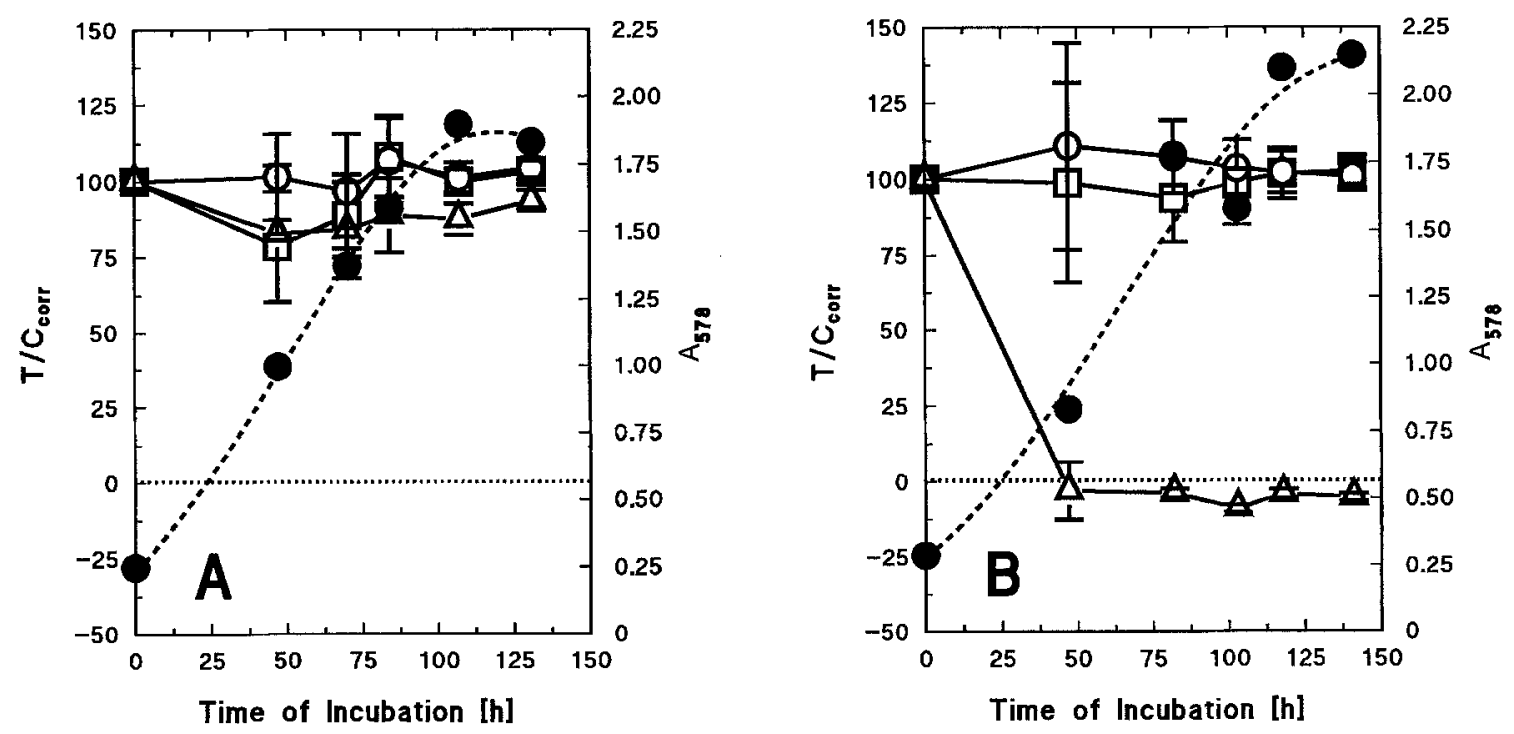

Fig. 2A,B. Effect of miltefosine treatment on the proliferation of two subtypes of the murine MXT mammary carcinoma in vitro. Plots of corrected T/C values versus time of incubation. $O, 1 \mu M ; \square, 10 \mu M ; \Delta, 100 \mu M$ miltefosine. ---, The growth of the (distilled water) controls (○). A MXT- cell line (in passage 26) derived from the hormone-independent MXT (M3.2) OVEX tumour. B MXT ${ }^{+}$cell line (in passage 32) derived from the ovary-dependent MXT (M3.2) tumour 

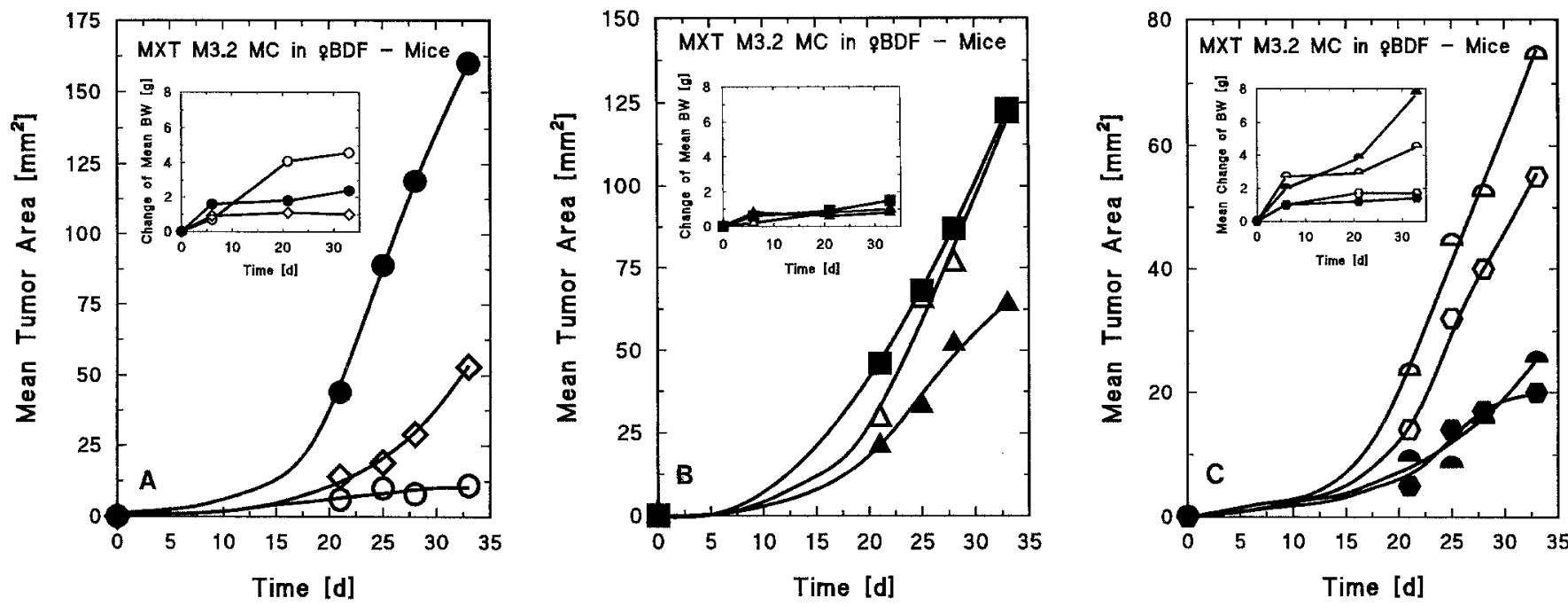

Fig. 3A-C. Growth curves of subcutaneously implanted ovary-dependent MXT (M3.2) mammary carcinoma in female B6D2F mice. A Hormone dependence of this tumour was demonstrated by strong tumour growth inhibition after ovariectomy $(\mathrm{O})$ and tamoxifen $(8 \mathrm{mg} / \mathrm{kg}, \mathrm{s.c} .3$ times weekly) treatment $(\diamond)$ in comparison with untreated control $(\mathbf{O})$. Inset shows typical increase in body mass of ovariectomized animals. B Miltefosine at a concentration of $16 \mathrm{mg} / \mathrm{kg}$, p.o. $(\triangle)$ did not influence tumour growth compared with the p.o. control $(\mathbf{\square})$. A dose of $32 \mathrm{mg} / \mathrm{kg}$, p.o. miltefosine $(\Delta)$ significantly $(P<0.01)$ inhibited MXT (M3.2) tumour growth. During the course of the experiment the body masses of the mice remained almost unchanged. C Hormone-like platinum complex A $(\triangle)$ as well as cisplatin ( $\square$ ) inhibited MXT (M3.2) tumours at equimolar doses of $3 \mu \mathrm{mol} / \mathrm{kg}$, s.c. (three times weekly) significantly $(P<0.01$, compared with controls in $\mathbf{A})$. When miltefosine at the ineffective dose of $16 \mathrm{mg} / \mathrm{kg}$ p.o. was given in combination with these platinum complexes (with complex A, $\mathbf{0}$; with cisplatin, $\mathbf{O}$ ) their antitumour activity was significantly enhanced (complex A + miltefosine: $P<0.01$; cisplatin + miltefosine: $P<0.05$ ). Inset shows strong increase in body mass in animals treated with platinum complex $\mathrm{A}$

weekly, s.c.) (Fig. 3C) (cf. Spruß et al. 1990). Additional miltefosine therapy at a dose of $16 \mathrm{mg} / \mathrm{kg}$, which was ineffective as monotherapy in this tumour experiment, could significantly enhance antitumoral effects of these platinum complexes (Fig. 3C) (Spruß et al. 1989).

These results were confirmed by determining mean tumour wet masses at the end of the MXT (M3.2) experiment (Fig. 4).

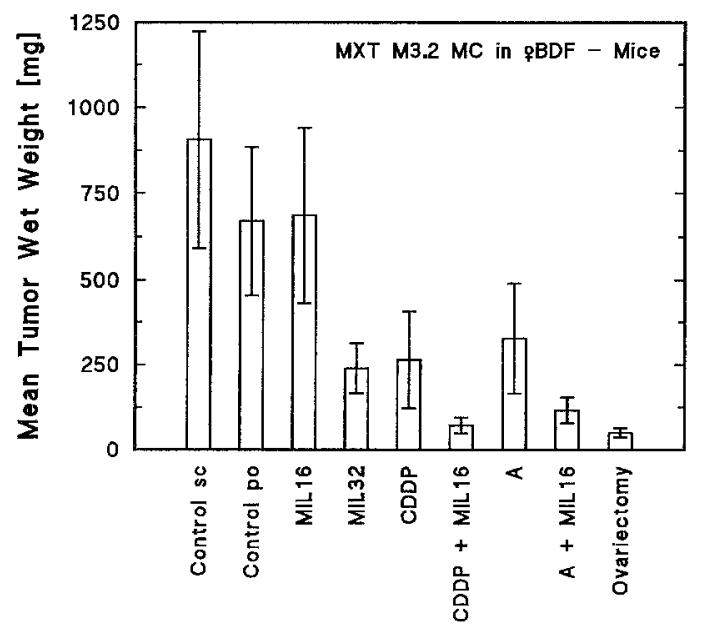

Fig. 4. Wet weights of MXT (M3.2) tumours at the end of experiment (see Fig.3). At a dose of $16 \mathrm{mg} / \mathrm{kg}$ (MIL 16) miltefosine alone was ineffective but reduced tumour wet masses in combination with cisplatin $(C D D P+M I L 16)$ significantly with $P<0.01)$. In combination with the hormone-like platinum complex $\mathrm{A}(A+M I L 16)$ tumour reduction was also significant $(P<0.05)$. The doses of cisplatin and complex $\mathrm{A}$ were $3 \mu \mathrm{mol} / \mathrm{kg}$.(three times weekly, s.c.)
Histology of MXT (M3.2) tumours after treatment with miltefosine alone and in combination with platinum complexes

All s.c. implanted tumours were encapsulated by collagen fibres and no infiltrative or invasive growth could be observed, irrespective of therapy. The histology of untreated MXT (M3.2) tumours showed a moderately differentiated adenocarcinoma. Epithelial cells were arranged in irregular sheets or ductular structures with little stroma. The detail in Fig.5A shows moderate differentiation towards ductal or papillary formations. In contrast to the original MXT tumour described by Watson et al. (1977), the MXT (M3.2) variant used in our studies was less differentiated, but exhibited a similar response to hormonal therapy.

Treatment with miltefosine ( $32 \mathrm{mg} / \mathrm{kg}$, p.o.) led to a marked loss of differentiated tumour structures. The histological appearance of the carcinoma (Fig. 5B) resembled that of the hormone-independent MXT variant MXT (M3.2) OVEX, which is a fast-growing anaplastic carcinoma. Only scanty stroma appeared between the irregularly arranged tumour cells.

The characteristic changes in tumour microarchitecture caused by the hormone-like platinum complex A were an increase in ductular structures lined by a single layer of epithelial cells. Irregularly organized epithelial carcinoma cells formed sheets between the ductular structures (Fig. 5C).

Combination therapy with miltefosine and the platinum complex A completely changed the microarchitecture of the MXT (M3.2) tumour (Fig. 5D). Most of the tumour epithelial cells were arranged in elongated ductular structures that were formed by one single layer of epithelium. Undifferentiated tumour parts were rare and stroma was scanty. 

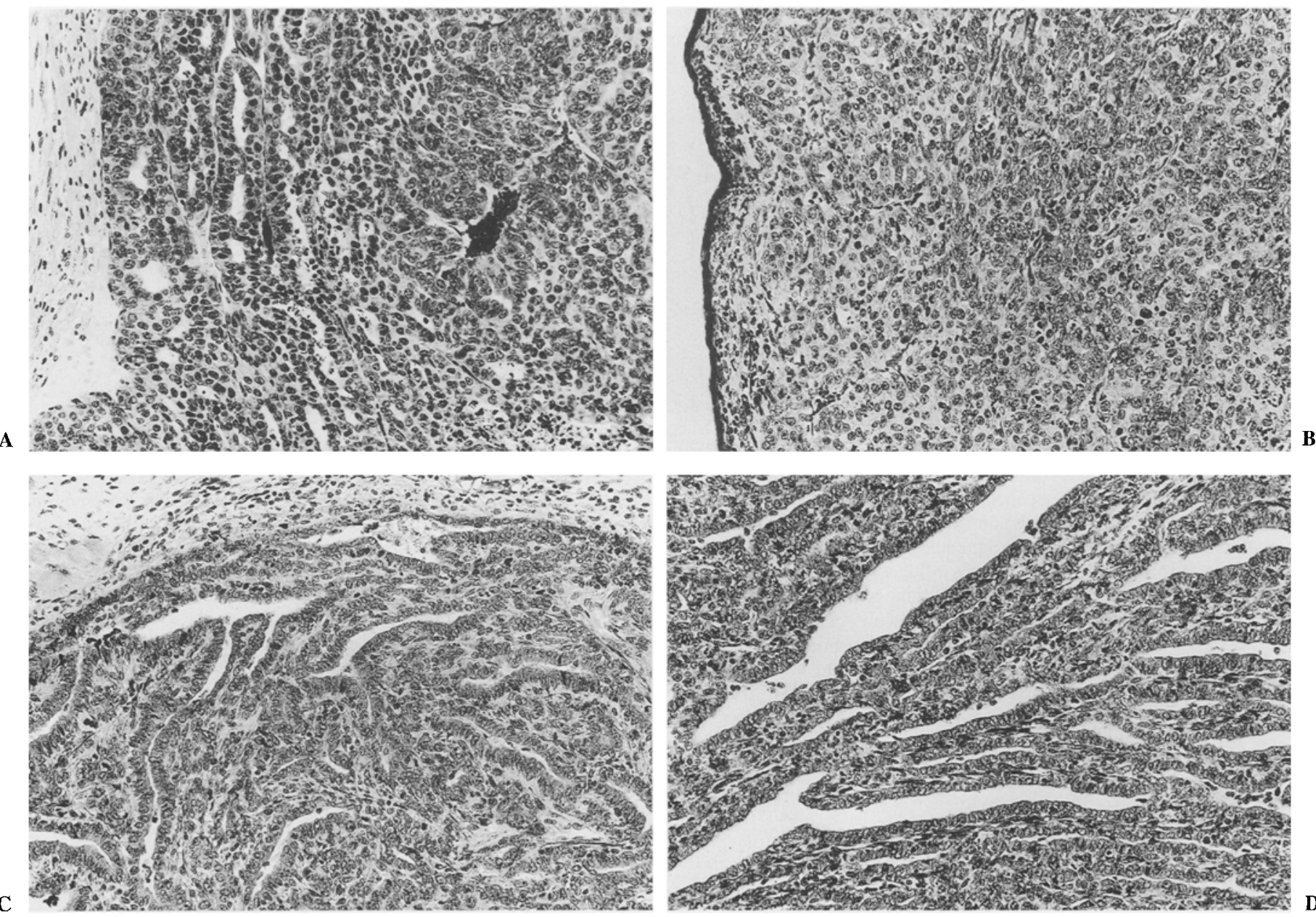

Fig. 5A-D. Histology of the MXT (M3.2) tumour after different therapies. Masson-Goldner-Jerusalem stained, all $\times 180$. A Subcutaneously growing tumour of an untreated mouse resembles a moderately differentiated adenocarcinoma. B Treatment with miltefosine (32 $\mathrm{mg} / \mathrm{kg})$ led to an almost complete loss of differentiated tumour structures. After treatment the undifferentiated tumour is similar to the hormone-independent MXT (M3.2) OVEX carcinoma. C An increase in epithelial tumour cells, organized in large ductular structures, is typical for tumours treated with hormone-like platinum complex A. Undifferentiated tumour cell formations appear between these highly differentiated structures. D Combination therapy with platinum complex A and miltefosine led to an almost complete loss of undifferentiated formations. Most of the tumour cells are organized in large elongated ductular structures

\section{Morphometric analysis of MXT (M3.2) tumours after treat- ment with miltefosine alone and in combination with plati- num complexes}

Morphometric analysis of tumour cell nuclei was carried out to quantify morphological changes of nuclei from differentiated and from undifferentiated tumour cell populations.

The differentiated tumour cell populations were epithelial cells forming acini or ductular structures, whereas irregularly arranged tumour cells represented anaplastic tumour areas. In untreated controls, both cell types had a mean nuclear area of about $30 \mu \mathrm{m}^{2}$ (Fig. 6). Whereas miltefosine at a dose of 16 $\mathrm{mg} / \mathrm{kg}$ did not change these parameters, a dose of $32 \mathrm{mg} / \mathrm{kg}$ led to an increase in nuclear size of undifferentiated tumour cell formations. Typical for cisplatin was an increase in nuclear area of both tumour cell types.

Only a slight increase in nuclear area was registered after treatment with platinum complex A. The combination of miltefosine and cisplatin did not change these morphometric parameters significantly, i.e. miltefosine, administered in combination therapy at a concentration of $16 \mathrm{mg} / \mathrm{kg}$, did not affect the size of tumour cell nuclei.

\section{Discussion}

In the literature several modes of action of miltefosine and the structurally related alkyllysophospholipids including direct cytotoxic activity (Berdel et al. 1981), inhibition of phosphatidylcholine biosynthesis (Haase et al. 1991), induction of differentiation (Hilgard et al. 1989) and interference with signal transduction processes, especially inhibition of protein kinase C (Überall et al. 1991), are discussed. However, the precise mechanism of the tumour-inhibiting activity of miltefosine is not yet understood. This motivated us to investigate further the activity of miltefosine against MXT mouse mammary carcinomas in vitro and in vivo.

Chemosensitivity experiments showed a striking specificity of $100 \mu M$ miltefosine against the hormone-dependent 


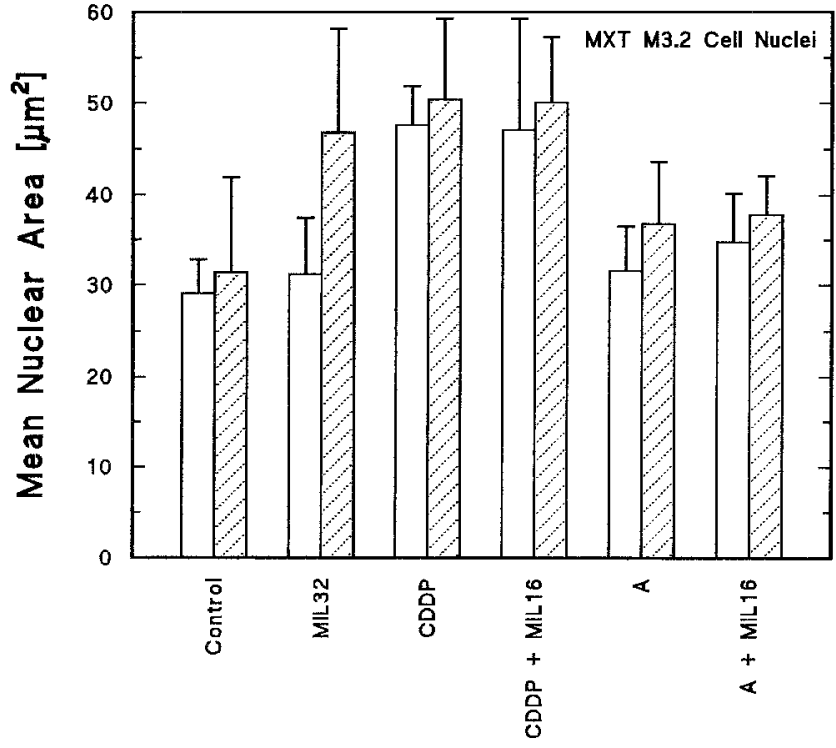

Fig. 6. Morphometric data from untreated MXT (M3.2) tumours show that tumour cell nuclei from highly differentiated structures (open columns) and nuclei from undifferentiated cell formations (hatched columns) have similar sizes. Cisplatin therapy ( $C D D P)$ leads to typical enlargement of all tumour cell nuclei, while miltefosine therapy $(32 \mathrm{mg} / \mathrm{kg}$ p.o., MIL32) only increased the size of the nuclei of the undifferentiated tumour areas. At a dose of $16 \mathrm{mg} / \mathrm{kg}$ p.o. (MIL1O) miltefosine did not influence nuclear areas of tumour cells when combination therapies with platinum complexes were performed. $A$, platinum complex $\mathrm{A}$

$\mathrm{MXT}^{+}$, a dose where the hormone-independent $\mathrm{MXT}^{-}$variant was not affected. The cytocidal dose (Fig. 2) of $100 \mu M$ may seem very high, but Kötting et al. (1992) reported therapeutic serum levels of $120 \mu M$ miltefosine in rats and Unger et al. (1990a) measured steady-state plasma levels of $100-200 \mu \mathrm{mol} / 1$ in patients 2 weeks after daily treatment with 50-200 mg miltefosine.

In vivo the proliferation of the anaplastic MXT (M3.2) OVEX tumour was not inhibited by $32 \mathrm{mg} / \mathrm{kg}$ miltefosine whereas the ovary-dependent, moderately differentiated MXT (M3.2) tumour was significantly reduced. The lack of antitumoral activity of miltefosine against the hormone-independent MXT (M3.2) OVEX tumour in vivo is in accordance with the work of Muschiol et al. (1987) and Yanapirut et al. (1991). Since the MXT (M3.2) breast cancer model is extremely sensitive to hormonal manipulation (Spruß et al. 1991) this experiment could not exclude the possibility that tumour reduction was caused by some hormonal activity of miltefosine, although Hilgard et al. (1990a) suggested that the therapeutic activity of miltefosine was independent of the hormone receptor status of the tumour. We could clearly demonstrate, by the uterine mass test in the juvenile mouse, that miltefosine lacks (anti)oestrogenic activity. In contrast to previously reported results (Muschiol et al. 1987) we found no signs of gastrointestinal toxicity of miltefosine. The toxic effects reported by Muschiol et al. (1987) in SpragueDawley rats could not be observed in our experiments carried out with $\mathrm{B} 6 \mathrm{D} 2 \mathrm{~F}_{1}$ mice. Livers and spleens of the mice were macroscopically not affected and histological examinations showed no signs of toxic action to the gastrointestinal tract. A slight decrease in body mass during the course of the ex- periment was due to daily p.o. application, and not caused by drug action.

Whereas Hilgard et al. (1989) demonstrated induction of differentiation in dimethylbenz $[a]$ anthracene-induced mammary tumours of rats, the differentiated MXT (M3.2) tumours were transformed to anaplastic carcinomas after the treatment with miltefosine in vivo. Modulation of differentiation seems to be a very complex process and miltefosine can paradoxically induce or inhibit differentiation depending on the special nature of the tumour investigated. While Hochhuth et al. (1990) induced differentiation by treating U937 cells with a phorbol ester or with miltefosine, Shoji et al. (1991) inhibited phorbol-ester-induced differentiation of HL60 cells by miltefosine treatment.

Morphological changes such as formation of „apoptotic bodies", pyknosis, and lysis of nuclei in MXT (M3.2) tumours are considered typical of apoptosis (Tomei and Cope 1991). Szende et al. (1990) postulated, that these changes are associated with hormonally induced tumour regression, whereas in our experiments formations like apoptotic bodies, pyknosis and specific lysis of tumour cell nuclei were equally distributed in tumour sections of the controls and all treatment groups. In our opinion apoptosis, a hypothetically distinct type of cell death (Kerr and Harmon 1991), does not contribute to tumour regression neither by miltefosine, platinum complexes or tamoxifen nor by ovarectomy.

Weisbrod et al. (1990) found additive or synergistic antitumoral effects by combining ilmofosine with a variety of cytostatics including cisplatin in vitro. In our in vitro experiments a combination of cisplatin and miltefosine did not enhance platinum cytotoxicity against human breast (MDAMB-231, MCF-7) and ovarian cancer (SK-OV-3) cell lines (data not shown). On the contrary, in vivo combination therapy of miltefosine with cisplatin and a hormone-like platinum complex led to a significant enhancement of the antitumour activity of these compounds on MXT M3.2 mammary carcinoma. These combinations were non-toxic.

Muschiol et al. (1988) reported an accelerated tumour growth of methylnitrosourea-induced rat mammary carcinomas treated with a combination of tamoxifen and miltefosine. This combination therapy in rats caused severe toxic effects that even led to death of the animals. Tumour-infiltrating leucocytes, which massively invade many experimental rodent tumours during regression (Schreiber 1989), were rarely observed in MXT mammary carcinomas after miltefosine therapy. Since xenografted tumours in nude mice could effectively be treated with miltefosine (Voegeli et al. 1990; Hilgard et al. 1991) there is no experimental evidence that miltefosine action is mediated by the host's immune system.

These findings are consistent with our results obtained after implantation of the ovary-dependent MXT (M3.2) mammary carcinoma into T-cell-deficient NMRI mice. A daily dose of $32 \mathrm{mg} / \mathrm{kg}$ p.o. of miltefosine led to about $60 \%$ tumour inhibition.

From our in vitro and in vivo experiments using the two variants of the MXT mouse mammary carcinoma we conclude, that no hormonal effects can be involved in the mechanism of action of miltefosine. Differences other than hormone sensitivity or type of differentiation of these tumour variants, such as inhibition of protein kinase $\mathrm{C}$, must be re- 
sponsible for the highly specific activity against the moderately to well-differentiated MXT (M3.2) mammary adenocarcinoma of the $\mathrm{B} 6 \mathrm{D} 2 \mathrm{~F}_{1}$ mouse.

Remark: Meanwhile a clinical study by Winkelmann et al. (1992) demonstrated dose-limiting gastrointestinal toxicity of p.o. treatment with ilmofosine. The authors conclude that treatment with oral ilmofosine is not effective in patients with liver metastases due to various malignancies.

Acknowledgements. This work was supported by the Bundesministerium für Forschung und Technologie. The authors thank Maria Rustler, Petra Pistor, Oskar Baumann and Franz Wiesenmeyer for excellent technical assistance and referee 1 for helpful criticism.

\section{References}

Andreesen R, Munder PG (1990) Modulation in vitro of human immune effector cell function by ether-lipid analogues. J Cancer Res Clin Oncol 116 [Suppl II]:994

Beckenlehner K (1991) Etablierung und Charakterisierung muriner Mammacarcinom-Zellinien (MXT) zur vergleichenden Prüfung neuer Antitumorwirkstoffe. Diplomarbeit im Fachbereich Biologie der Universität Regensburg

Berdel WE, Fink U, Egger B, Reichert A, Munder PG, Rastetter J (1981) Inhibition by alkyllysophospholipids of tritiated thymidine uptake in cells of human malignant urologic tumors. J Natl Cancer Inst 66:813

Bernhardt G, Reile H, Birnböck H, Spruß T, Schönenberger H (1992) Standardized kinetic microassay to quantify differential chemosensitivity based on proliferative activity. J Cancer Res Clin Oncol 118:35

ten Bokkel Huinink WW, Hilton A, Somers R (1992) Topical application of miltefosine against skin metastases of breast cancer. NCIEORTC symposium on new drugs in cancer therapy, Amsterdam, March 17-20, 1992, abstract 27, [Suppl. I] to Vol. 3 Annal. Oncol.

De Cesare M, Dal Bo L, Pratesi G, Zunino F, Giuliani F, Tognella S (1992) Increased antitumor efficacy of cisplatin by ilmofosine combination against xenografted human lung tumors. NCI-EORTC symposium on new drugs in cancer therapy, Amsterdam, March 17-20, 1992, abstract 192, [Suppl. I] to Vol. 3 Annal. Oncol.

Haase R, Wieder T, Geilen CC, Reutter W (1991) The phospholipid analogue hexadecylphosphocholine inhibits phosphatidylcholine biosynthesis in Madin-Darby canine kidney cells. FEBS Lett 228:129

Herrmann DBJ, Opitz H-G, Munder PG (1992a) Synergistic combination effect of oral ilmofosine and oral cyclophosphamide in the Lewis-lung carcinoma model. J Cancer Res Clin Oncol 118[Suppl]:R147

Herrmann DBJ, Opitz H-G, Munder PG (1992b) Synergistic antitumor activity of combined oral ilmofosine and i.v. cisplatin in a murine methA fibrosarcoma model. $\mathrm{J}$ Cancer Res Clin Oncol 118[Suppl]:R147

Hilgard P, Stekar J, Voegeli R, Engel J, Schumacher W, Eibl H, Unger C, Berger MR (1988) Characterization of the antitumor activity of hexadecylphosphocholine (D 18506). Eur J Cancer Clin Oncol 24:1457

Hilgard P, Harleman JH, Voegeli R, Maurer HR, Echarti C, Unger C (1989) Induction of differentiation as a possible mechanism for the antineoplastic activity of hexadecylphosphocholine. J Cancer Res Clin Oncol 115[Suppl]:54

Hilgard P, Stekar J, Voegeli R, Fenneberg K, Unger C (1990a) Action of miltefosine in dimethyl-benzanthracene(DMBA) induced mammary carcinomas in Sprague Dawley rats, relapsing after ovariectomy. J Cancer Res Clin Oncol 116[Suppl I):617

Hilgard P, Stekar J, Sindermann H, Peukert M, Unger C (1990b) Antineoplastic activity of alkylphosphocholines in vivo. J Cancer Res Clin Oncol 116[Suppl II):889
Hilgard P, Kampherm E, Nolan L, Pohl J, Reissmann T (1991) Investigation into the immunological effects of miltefosine, a new anticancer agent under development. J Cancer Res Clin Oncol 117: 403

Hochhuh C, Berkovic D, Eibl H, Unger C, Doenecke D (1990) Effects of antineoplastic phospholipids on parameters of cell differentiation in U937 cells. J Cancer Res Clin Oncol 116:459

Honma Y, Kasukabe T, Hozumi M, Tusushima S, Nomura H (1981) Induction of differentiation of cultured human and mouse myeloid leukemia cells by alkyllysophospholipids. Cancer Res 41:3211

Honma Y, Kasukabe T, Okabe-Kado J, Hozumi M, Tusushima S, Nomura H (1983) Antileukemic effect of alkylphospholipids: I. Inhibition of proliferation and induction of differentiation of cultured myeloid leukemia cells by alkylethyleneglycophospholipids. Cancer Chemother Pharmakol 11:73

Karl J, Gust R, Spruß Th, Schneider MR, Schönenberger H, Engel J, Wrobel K-H, Lux F, Trebert-Haeberlin S (1988) Ring-substituted [1,2-bis(4-hydroxyphenyl)ethylenediamine]dichloroplatinum(II) complexes: compounds with a selective effect on the hormone dependent mammary carcinoma. J Med Chem 31:72

Kerr JFR, Harmon BV (1991) Definition and incidence of apoptosis: an historical perspective. Tomei LD, Cope FO (eds) Apoptosis: the molecular basis of cell death. Cold Spring Harbor Laboratory, New York, $\mathrm{p} 5$

Kötting J, Berger MR, Unger C, Eibl H (1992) Antitumoral activity and biodistribution of hexadecylphosphocholine and of homologues. NCI-EORTC symposium on new drugs in eancer therapy, Amsterdam, March 17-20, 1992, abstract 25, [Suppl. I] to Vol. 3 Annal. Oncol.

Muschiol C, Berger MR, Schuler B, Scherf HR, Garzon FT, Zeller WJ, Unger C, Eibel HJ, Schmähl D (1987) Alkyl phosphocholines: toxicity and anticancer properties. Lipids 22:930

Muschiol C, Berger MR, Eibl HJ, Schmähl D (1988) Combination chemotherapy of methylnitrosurea (MNU) - induced rat mammary carcinoma with hexadecylphosphocholine and tamoxifen. J Cancer Res Clin Oncol 114[Suppl]:S39

Reile H, Birnböck H, Bernhardt G, Spruß T, Schönenberger H (1990) Computerized determination of growth kinetic curves and doubling times from cells in microculture. Anal Biochem 187:262

Scherf HR, Schuler B, Berger MR, Schmähl D (1987) Therapeutic activity of ET-18-OCH ${ }_{3}$ and hexadecylphosphocholine against mammary tumors in BD-VI rats. Lipids 22:927

Schreiber H (1989) Tumor immunology. In: Paul WE (ed) Fundamental immunology. Raven, New York, p 923

Shoji M, Raynor RL, Fleer EA, Eibl H, Vogler WR, Kuo JF (1991) Effects of hexadecylphosphocholine on protein kinase $\mathrm{C}$ and TPA-induced differentiation of HL60 cells. Lipids 26:145

Sokal RR, Rohlf FJ (1987) Introduction to biostatistics (2nd edn). Freeman, New York, pp 220

Spruß Th, Bernhardt G, Reile H, Schönenberger H, Engel J (1989) Combination therapy with platinum complexes and hexadecylphosphocholin of MXT-mouse mammary adenocarcinomas. J Cancer Res Clin Oncol 115[Suppl]:55

Spruß Th, Gust R, Müller R, Engel J, Schönenberger H (1990) Mammary tumor inhibiting properties of the $(S, S)$-configurated [1,2-bis(4hydroxyphenyl)ethylenediamine]dichloroplatinum(II)-complexes. Arch Pharm (Weinheim) 323:99

Spruß Th, Bernhardt G, Schickaneder E, Schönenberger H (1991) Different response of murine and human mammary tumour models to a series of diastereoisomeric [1,2-bis(difluorophenyl)ethylenediamine]dichloroplatinum(II) complexes. J Cancer Res Clin Oncol 117:435

Szende B, Srkalovic G, Groot K, Lapis K, Schally AV (1990) Growth inhibition of mouse MXT mammary tumor by the luteinizing hormone-releasing hormone antagonist SB-75. J Natl Cancer Inst $82: 513$

Tomei LD, Cope FO (eds) (1991) Apoptosis: the molecular basis of cell death. Cold Spring Harbor Laboratory Press, New York

Überall F, Oberhuber H, Maly K, Zaknun J, Demuth L, Grunicke HH (1991) Hexadecylphosphocholine inhibits inositol phosphate formation and protein kinase $\mathrm{C}$ activity. Cancer Res 51:807 
Unger C, Eibl H, Heyden von HW, Peukert M, Sindermann H, Nagel GA (1990a) Phase I study with daily hexadecylphosphocholine in patients with malignant disease. J Cancer Res Clin Oncol 116[Suppl II]:993

Unger C, Peukert M, Sindermann H, Hilgard P, Nagel G, Eibl H (1990b) Hexadecylphosphocholine in the topical treatment of skin metastases in breast cancer patients. Cancer Treat Rev 17:243

Voegeli R, Echarti C, Hilgard P, Stekar J, Maurer HR, Unger C, Schumacher W, Nössner G, Kutscher B, Engel J (1990) An in vitro screening system for phospholipids with antitumor activity. J Cancer Res Clin Oncol 116[Suppl I):452

Watson C, Medina D, Clark JH (1977) Estrogen receptor characterization in a transplantable mouse mammary tumor. Cancer Res $37: 3344$

Watson C, Medina D, Clark JH (1980) Characterization of progesterone receptors, estrogen receptors, and estrogen (type II)-binding sites in the hormone-independent variant of the MXT-3590 mouse mammary tumor. Endocrinology 107:1432

Weisbrod AK, Herrmann DBJ, Pahlke W, Bicker U, Opitz HG (1990) Combination chemotherapeutic effects of ilmofosine and other cytostatics in vitro. J Cancer Res Clin Oncol 116[Suppl I):616

Winkelmann M, Ebeling K, Strohmeyer G, Hottenrott G, Mechl Z, Berges W, Scholten T, Westerhausen M, Schlimok G, Sterz R (1992) Treatment results of the thioether lipid ilmofosine in patients with malignant tumors. J Cancer Res Clin Oncol 118:405-407

Yanapirut P, Berger MR, Reinhardt M, Schmähl D (1991) In vitro investigations on the antineoplastic effect of hexadecylphosphocholine. Arzneimittelforschung 41:652

Zheng B, Oishi K, Shoji M, Eibl H, Berdel WE, Hajdu J, Vogler WR (1990) Inhibition of protein kinase $C$, (sodium plus potassium)-activated adenosine triphosphatase, and sodium pump by synthetic phospholipid analogues. Cancer Res 50:3025 